\title{
GREECE DEBT CRISIS
}

\author{
Itika Majumder $^{1}$
}

\begin{abstract}
Revisiting the events around the Greek economy we highlight three factors that combined together to generate the Greek crisis. The first aspect is the political economic constitution of the European Union (EU) and European Monetary Union (EMU) within which Greece is a participant. Its pro-market integration with EU and EMU deepened the contradiction between economic adjustment and social improvement. Secondly, neoliberalism of Greece led to the rise of financialization within the Greek economy that locked it to the institutions and vagaries of the new global order and its shocks. Lastly, an understanding of the Political Economy of Greece and its relation to the state and politics leads us to explore the seed of its own destruction. What our analysis, following a Marxian perspective, shows are that the mutual constituted of these three factors exposed Greece into an economic crisis of unprecedented magnitude and depth.

Key Words: Greek Economy, Troika, Neoliberalism, Capitalism, Austerity
\end{abstract}

"What we are currently experiencing is the total triumph of neoliberalism. It spells the end of humanity" - Yanis Varoufakis, Ex Finance Minister of Greece.

\section{I.INTRODUCTION}

The subprime mortgage crisis (2007) hit the heart of financial system with its epicentre in the Wall Street and eventually spread all over the world with dire consequences for the USA economy and subsequently for the European economy. The contagion effect seems to culminate in the appearance of the Greek debt crisis (2009) which is our focus of interrogation. What started off as a financial crisis ended up with a full-fledged economic crisis.

It is our contention that the confluence of three factors explains how and why the economic crisis happened, pulling and pushing the crisis into various directions:

1. Political and economic constitution of the European Union (EU) and European Monetary Union (EMU) within which Greece became a participant.

2. Neoliberalism of Greece leading to the rise of financialization within the Greek economy.

3. The rise of Modern Greek economy in capitalist direction and its internal dynamics; and its relation to the state and politics that turned out, along with the above two, central to what transpired.

We intend to show how these three nodes combined together to produce what we name as "the Greek economy" and how in the process helped transform the Greek debt crisis into a full grown economic crisis." The fact that it is the combination of economic and political factors that is at the heart of this phenomenon justifies the title of our project, "Political economy of Greek debt crisis.

\section{FORMATION OF THE NODES OF MODERN GREEK ECONOMY}

POLITICAL-ECONOMIC FORMATION OF EUROPEAN UNION (EU), EUROPEAN MONETARY UNION (EMU) AND THE INTEGRATION OF GREECE

${ }^{1}$ Department of Economics University of Calcutta, Kolkata, West Bengal, India 
1) The economic motive behind the formation of EU was to create a larger common ('single') market which would promote competition. It would, in turn, lead to higher productivity. Thus, higher growth would happen and by the logic of trickle down, the standard of living would be improved.

2) The political motive was to create a supra-national organization which would provide a roof for the countries. It was assumed that it would lower the possibility of war among European nations. Another reason was the competition with US over the command on resources which these countries believed would be better served through integration.

3) A third motive was to institutionalize political democracy among the European nations. This aspect was central to the formation of EU as a bulwark against the Soviet Union and its expansionary threat.

The EMU represented a major step in the integration of EU economies. It involves the coordination of economic and fiscal policies, a common monetary policy, and a common currency, the euro. Together, these countries make up the euro area. Those EU countries that were integrated further into EMU had to accept the following conditions:

1. Coordination of economic policy-making between Member States. 2. Coordination of fiscal policies, notably through limits on government debt and deficit 3 . An independent monetary policy runs by the European Central Bank (ECB). 4. Single rules and supervision of financial Institutions within the euro area 5. The single currency and the euro area ${ }^{2}$

One important aspect of joining the EMU was that while countries would have some fiscal independence, the domain of monetary policy had to be given up to the ECB. This truncation of policy autonomy became a matter of political consideration in many instances where countries such as United Kingdom decided against joining the EMU. It also proved to be central as how the Greek crisis was to be seen and managed, not by Greek policy makers but by Troika. After political democracy was established, the Greek government aimed at integrating the country into the EU as a full member. The reasons seem to be the following:

1) Greece contemplated the community to be the institutional body - the medium that would stabilise its democratic political system and institutions so as to minimise chances of a further military upsurge.

2) Accession to the community was regarded by Greece as a powerful factor that would contribute to the development and modernization of the Greek economy and society.

3) As a member of the European community, Greece wanted to be present in and have an impact on not only the process of European integration but also the configuration of the European model. ${ }^{3}$

\section{III.POLITICAL HISTORY OF GREECE - A FLASHBACK:}

During 1958-1973, Greece had monarchy although it came under seven years of the military dictatorship (1967-74). But the last few years of military dictatorship in Greece witnessed severe unrest among the rank and file. The negative impacts of international stagflation crisis influenced Greek economy. In 1973 Greece became a parliamentary republic and the first election was held in 1974. Two dominant political parties of Panhellenic Socialist Movement or PASOK (left wing party) and New Democracy (right wing party) came into existence. There were several other parties which were represented in parliament because of proportionate representation.

A Summary of Greek politics of 1974-2009 :

${ }^{2}$ http://ec.europa.eu/economy_finance/euro/emu/index_en.htm

${ }^{3}$ http://www.mfa.gr/en/foreign-policy/greece-in-the-eu/greeces-course-in-the-eu.html 

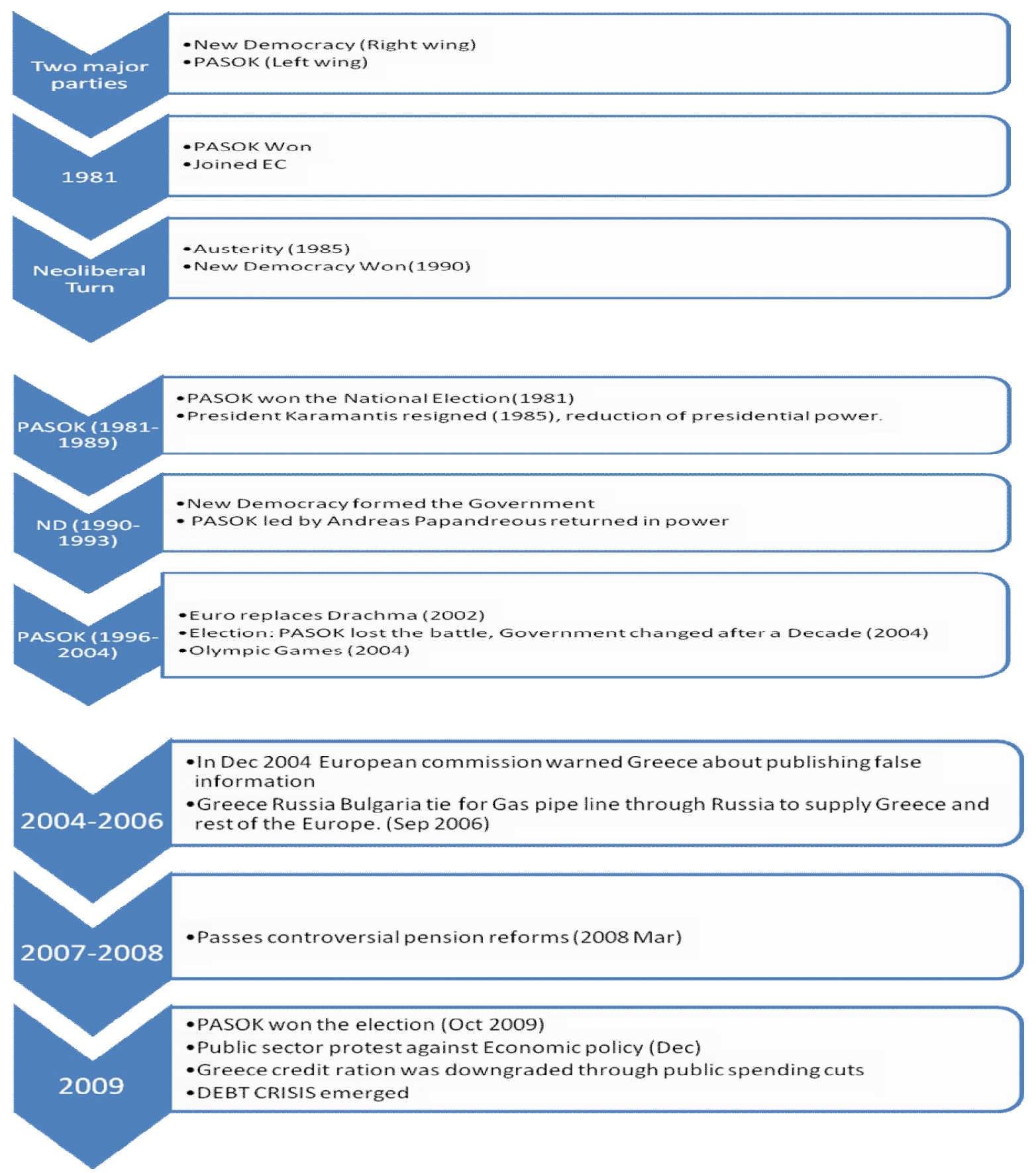

\section{IV.NEOLIBERALIZATION AND FINANCIALIZATION OF GREECE}

This ideology believes that there has to be a one to one relationship between capital and labor. Any kind of restrictions (such as trade union and protection) that stands between capital and labor and between producers and consumers should be dismantled or eroded. A new kind of (global) capitalism was envisaged from this neoliberal order. The gradual adoption of euro as the common currency and the EU expansion and integration into the new global economic order based on neoliberal principle entailed a massive restructuring of the financial system producing what many have described as the period of financialization. Financialization indicates the directive of increasing functions of financial motives, financial markets, financial actors and financial institutions in operations 
of domestic and international economies (Epstein 2005: 3). Financialization thus emerges as an offshoot of neoliberal reconstruction of capitalism.

The Greek banking system was offered institutional foundations to conduct financial deregulation and competition, after the entry of Greece into the EEC in 1981 and the single market program in late 1980s. However, this institutional change reflected financialization of contemporary global capitalism in general and European financial integration in particular. Regulatory reforms were aimed at the harmonization of the member states' banking legislation and administrative provisions ruling the establishment and business of credit institutions (Vives 1991).

- Why the turn to Neo-Liberalism - A review of Marxist Literature-

Radical economists and certain Marxists say that the institutional framework and the contradictions within neoliberalism (but not necessarily capitalism as such) led to the crisis (Kotz 2008, Kotz 2009). The neoliberal regime is seen as the institutional structure which followed the 'Keynesian compromise' of the post-war 'golden age', built on the constituent pillars: increased class inequality and income inequality, financialization, accumulation of debt and creation of asset bubbles.

\section{- Empirical investigation of Neo-Liberalism-}

In 1958-1973, fluctuation in rate of surplus and profit share was insignificant. They then rose steadily during years of military dictatorship (1967-1974) as labor unions were suppressed and all political parties were outlawed. (Fig-1) (Maniatis and Passas 2013: 631).

Figure-1: The rate of surplus value (RSV) and the profit share (P/Y), 1958-2009

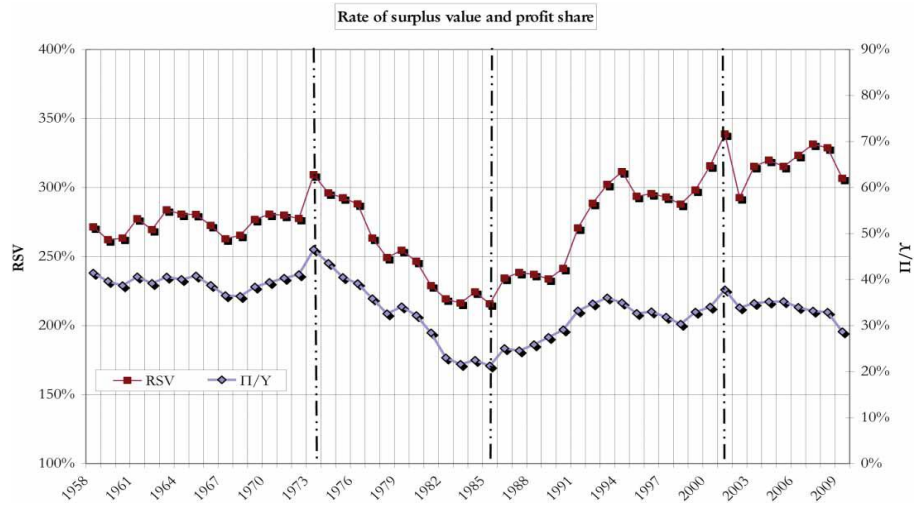

Source: Maniatis and Passas (2013)

Figure-2: The net rate of preofit 1958-2009 


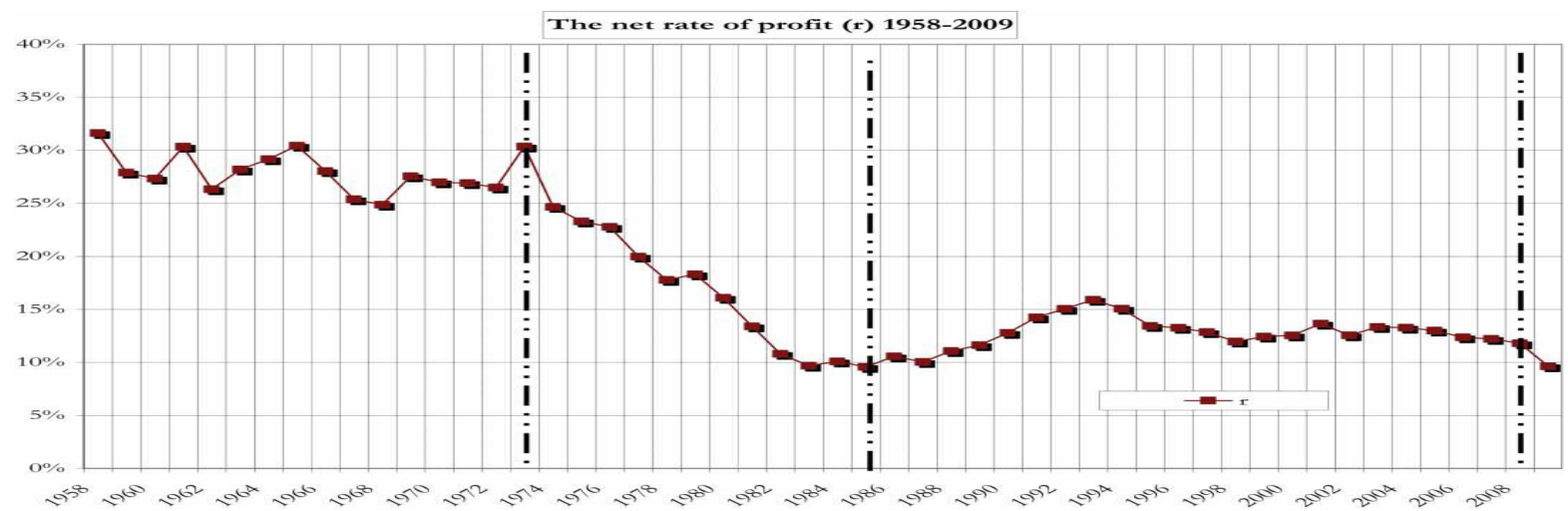

Source: Maniatis and Passas (2013)

Parliamentary democracy in 1974 followed the outbreak of international stagflation crisis in 1970s. Subsequently, the labor unions were legalized and their struggles were successful. The real wage of the workers increased significantly. Hence the rate of surplus value and profit share experienced a sharp fall. This continued through the years of first social democratic government of PASOK until 1985.

After the re-election of PASOK in 1985, its government implemented the first set of austerity measures, marking the beginning of neoliberal era in Greece.

The hourly wage rate for both labor employed in private sector and productive labor force declined continuously during the first half of the following 25 years. Then it stabilized during late 1990s and started to rise after 2000. Hourly wage rate of total labor force was close to its average value in mid 1980s (Fig-2).

Figure-3: Real wage index for total labor force and productive labor, 1960-2009

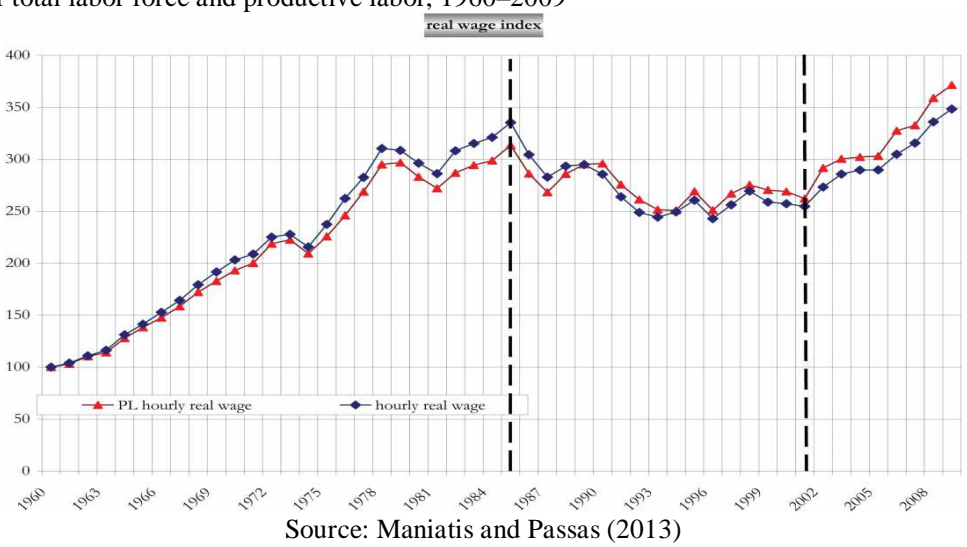

Due to long term stagnation in real wage since mid 1980s, rate of surplus value rose uninterrupted. It happened despite fall in productivity growth (Fig-3) (started in early 1980s and lasted until 1996), that was an inevitable result of fall in capital accumulation as profitability and output growth halted (Maniatis and Passas 2013: 631-35). 


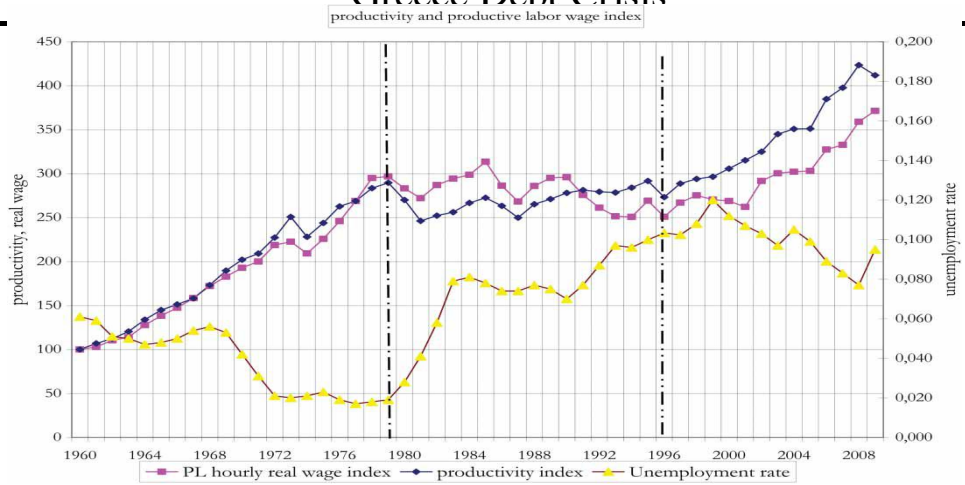

Figure-4: Unemployment rate, labor productivity index and real wage index for productive labor, 1960-2009

Source: Maniatis and Passas (2013)

Figure-4 also distinguishes the three broad phases of development of the real wage. In the first phase ('golden age') and third phase, rising productivity and falling unemployment rate led to increases in the real wage. On the contrary, during the latter part of the stagflation crisis and the first period of neoliberalism (1980-96), rising unemployment and productivity stagnation created a falling real wage trend.

Profit share and the profit-wage ratio experienced substantial rise in the neoliberal period pertaining to that productivity growth exceeded real wage growth (Figure-4).

Figure-5: Rate of surplus value and profit-wage ratio, 1958-2009

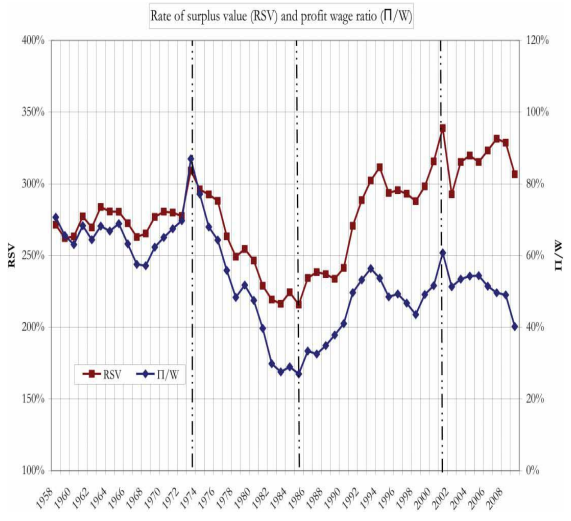

Source: Maniatis and Passas (2013)

After 1996, productivity growth picked up accompanied by real wage growth after 2001. This was temporarily halted during the 2002-2005 period, before the current crisis erupted and were reaped by capital. The stagnation in the real wage rate during almost the entire neoliberal period meant that all the benefits from productivity growth shifted the distribution of new value in its favor.

The neo-liberal solution led to debt driven consumption demand and government expenditure by deficit financing. Immediately after elimination of debt flow, the demand fell and real output got hampered.

\section{V.THE MODERN GREEK ECONOMY, DEBT CRISIS AND AUSTERITY}

Now, we divide the discussion into three parts: the performance of the Greek Economy (by the adoption of neoliberalism), that of debt crisis and finally the period of austerity which is still continuing. We begin by 
comparing the performance of the Greek Economy as a result of the implementation of the neoliberal package and that of austerity.

\subsection{The Greek performance: Emergence of two tales-}

Our analysis in the form of the figures below exhibit a vivid contrast between two Greece- the pre-and post-crisis of Greece. The neoliberal project in Greece produced a collapse of its capitalism so dramatic that it needed an international response to overcome it. However, what our analysis shows below is that while the response is in the form of austerity ending up producing a fiscal discipline it nevertheless led to a socio-economic disaster which in turn produced an international debate on Greece regarding the validity of the project of neoliberalism as a condition of capitalism and austerity as a medicine of overcoming the crisis.

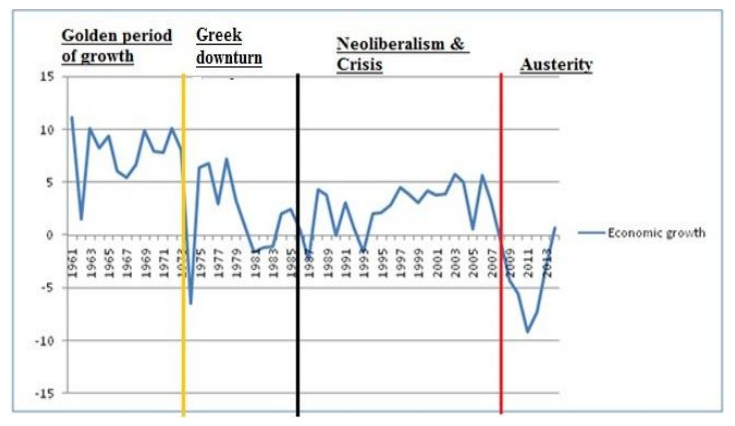

Figure-6: GDP growth rate of Greece

We have divided the whole scenario of Greece in four parts which are marked by the vertical lines. In Fig-6, the area between the black and the red line shows the neoliberalism period, where we can observe an increase in the GDP growth. But beyond the red line, i.e. after the crisis point and under the treatment of austerity, the growth rate has declined dramatically.

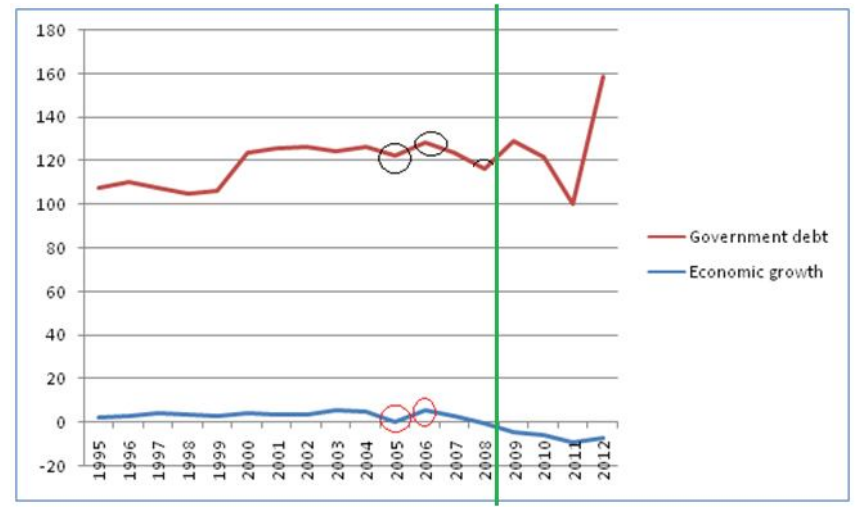

Figure-7: Government debt \& GDP Growth

In Fig-7, it shows a positive correlation between Government Debt \& GDP growth, i.e. the growth of Greece during the period of neoliberalism was debt financed. Here the green vertical line is used to compartmentalize the two distinct pictures, before and after the crisis point. So here it is seen that, after the crisis point, with the medicine of austerity, even with increasing government debt, there is a fall in the GDP growth. 


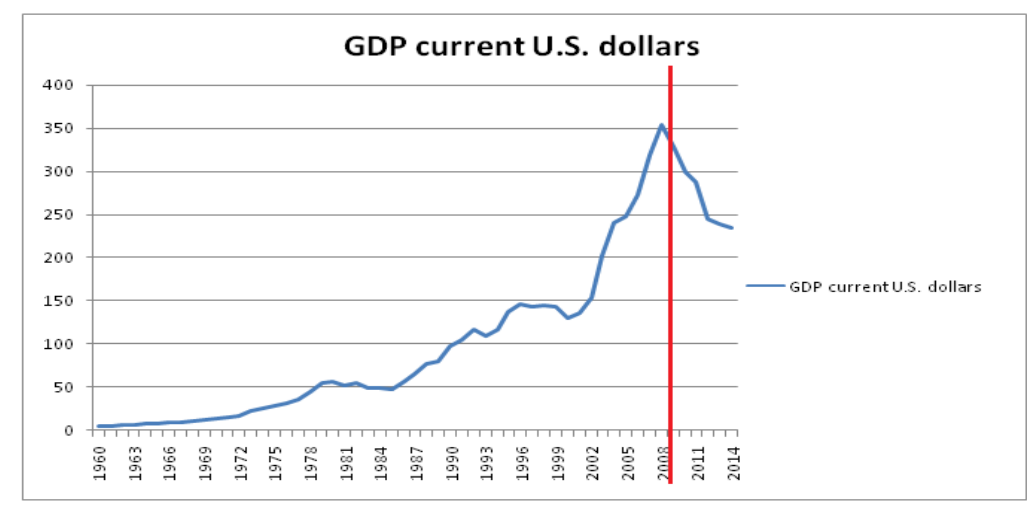

Figure-8: Greece GDP, at current U.S. dollars

In Fig-8, the red vertical line in the diagram is used to show the two compartments, one before the crisis point, i.e. 2008-09 where there has been a steady growth in the Greece GDP during the neoliberalism era \& another after the crisis point, where the GDP of Greece declined dramatically.

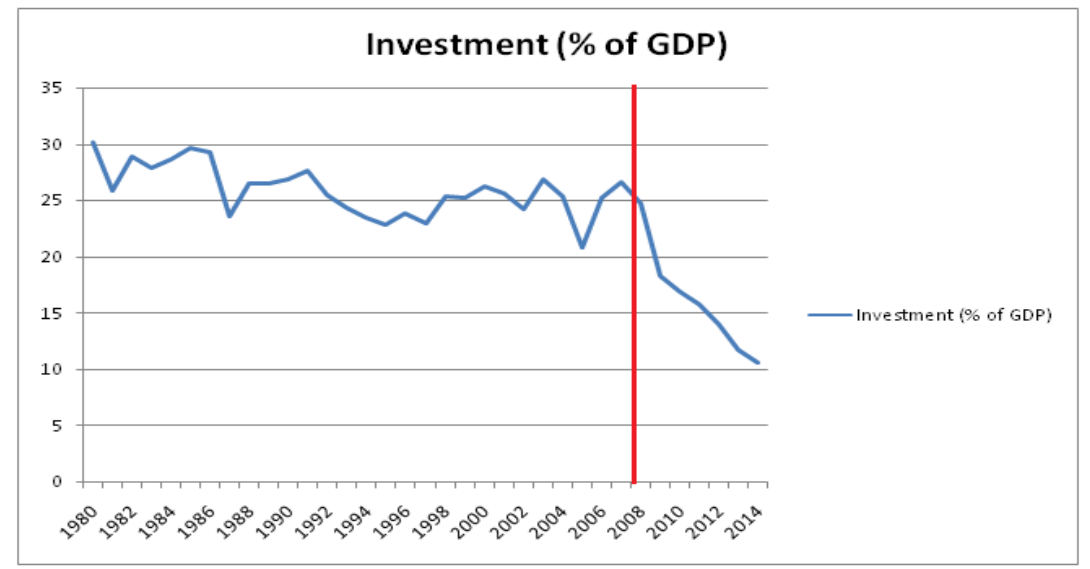

Figure-9: Total Investment (\% of GDP) of Greece

The red vertical line in Fig-9 shows the crisis point, after which investment have declined dramatically. Thus, it shows emergence of two tales of Greece - one during the period of pre-crisis $\&$ another that of post-crisis. 


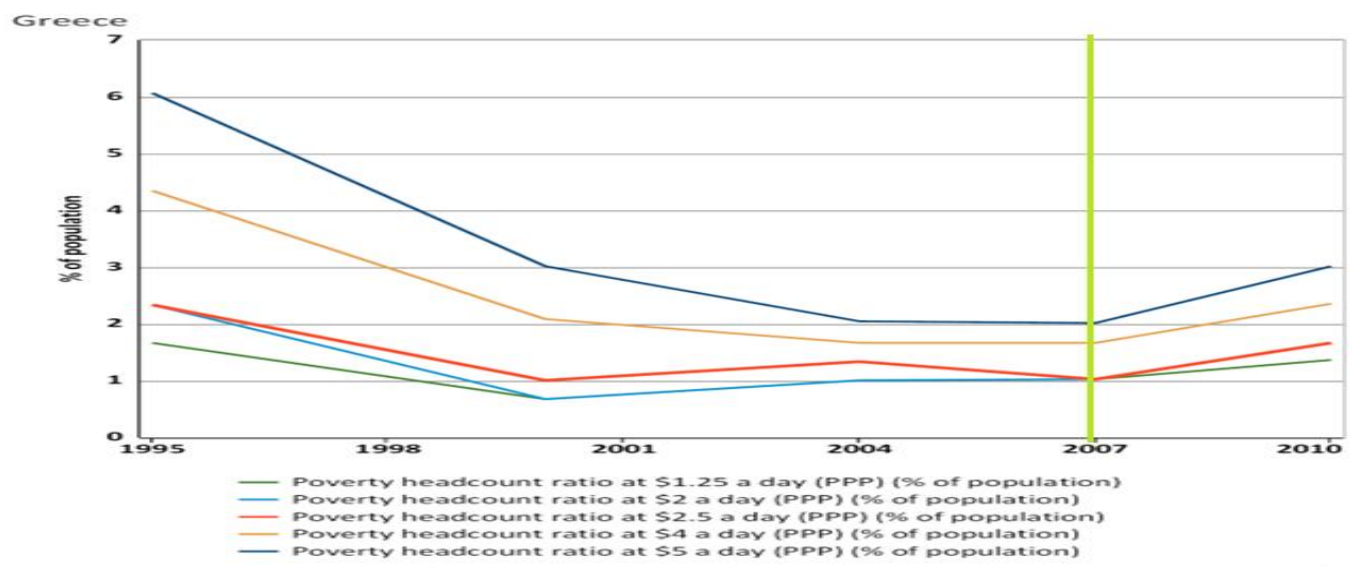

Figure-10: Poverty headcount ratio at different International Poverty Lines

Source: https://knoema.com/WBPS2015Jan/poverty-and-inequality-statistics

Fig-10, Here we have used the green vertical line to show the compartmentalized two pictures of Greece. First, the fall in poverty during the neoliberalism period or during the pre-crisis period and after the crisis point, with the therapy of austerity, the sharp increase in poverty.

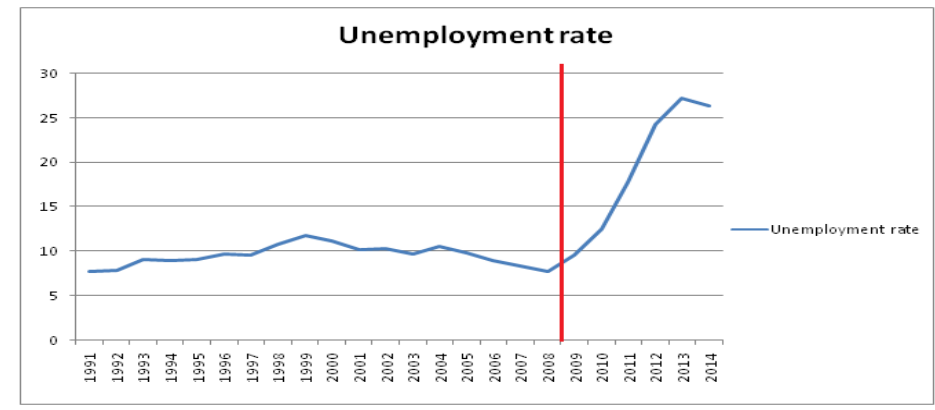

Figure-11: Greece Unemployment Rate

In Fig-11, We observe a steady unemployment rate during the neoliberalism era and a pronounced increase in the unemployment rate during the post-crisis period with austerity prevailing in the country.

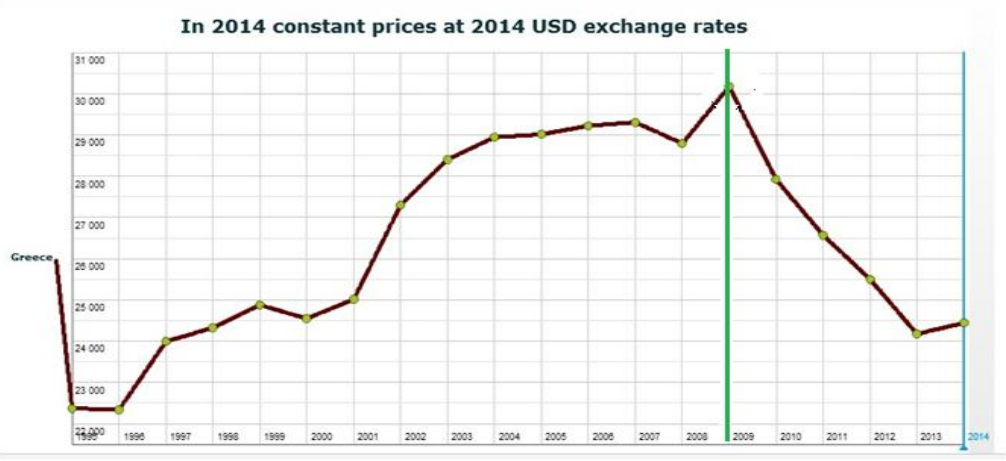

Figure-12: Average Annual wage of Greece (in 2014 U.S.D exchange rates) 
The green vertical line shows crisis point, after which the annual wage rate has fallen sharply, thus getting two distinct pictures of Greece, one before the crisis with neoliberalism and another after the crisis with austerity.

So, we can say that the growth during the neoliberalism era was actually an illusion, and it was nothing but the seed of destruction.

\section{VI.DEBT CRISIS}

In the decade before the global financial crisis (2008), the Greek government borrowed much externally to fund government budget and current account deficits (twin deficits). Between 2001, when Greece adopted the euro as its currency, and 2008, Greece's average budget deficit was $5 \%$ per year, compared to a Eurozone average of $2 \%$, and average current account deficit was $9 \%$ per year, compared to a Eurozone average of $1 \%$. This pushed up external debt (116\% of GDP in 2009). Both Greece's budget deficit and external debt level were well above those permitted by the rules of the EU's Economic and Monetary Union (EMU). Specifically, the Maastricht Treaty, calls for budget deficit ceilings of 3\% of GDP and external debt ceilings of 60\% of GDP (Nelson, Belkin, Mix 2010: 2-3).

\subsection{Outbreak of the current crisis-}

Since late 2009, investor confidence in the Greek government dwindled. In October 2009, the new socialist government, led by Prime Minister George Papandreou, revised the estimate of the government budget deficit for 2009 , nearly doubling the existing estimate of $6.7 \%$ of GDP to $12.7 \%$ of GDP. This was followed by downgrades of rating of Greek bonds by the three major credit rating agencies due to allegations that Greek governments had falsified statistics and attempted to obscure debt levels through complex financial instruments Before the crisis, Greek 10-year bond yields were 10 to 40 basis points above German 10-year bonds. With the crisis, this spread increased to 400 basis points in January 2010, which was at the time a record high. High bond spreads indicate declining investor confidence. However, the Greek government managed to sell $€ 8$ billion ( $\$ 10.2$ billion) in bonds at the end of January 2010, $€ 5$ billion ( $\$ 6.4$ billion) at the end of March 2010 , and $€ 1.56$ billion ( $\$ 1.99$ billion) in midApril 2010, at high interest rates. Greece needed an additional borrowing of $€ 54$ billion ( $\$ 68.8$ billion) for debt and interest payments in 2010. (Nelson, Belkin, mix 2010: 2-3) It had become clear by then that Greece had entered into a debt trap.

\subsection{Possible causes of the Greek crisis-}

A mix of domestic \& international factors is the reason for Greece's current economic problems.

\section{Domestic Factors:}

(a) High Government Spending and Weak Government Revenues

(b) Unsustainable Fiscal and External Imbalances

(c) Structural Policies and Declining International Competitiveness

\section{International Factors:}

(a) Increased Access to Capital at Low Interest Rates

(b) Issues with EU Rules Enforcement

\subsection{Austerity and the internationalization of Greece debt crisis-}


The need for longer-term structural reforms to the Greek economy has been repeatedly emphasized by Prime Minister Papandreou. He has proposed wide-ranging reforms to the pension and health care systems and to Greece's public administration. Some measurement for enhancing employment and economic growth, encouraging increased private sector development, and supporting research, technology, and innovation were announced by his government.

Maintaining public and political support for its austerity and economic reform program could perhaps be the most substantial challenge for the Greek government. In October 2009, Papandreou's Panhellenic Socialist Movement (PASOK) came to office on a platform of "social protection" which promised to boost wages, improve support for the poor, and promote redistribution of income. But most of these campaign pledges has been contradictory to what the actual policies adopted by his government turned out to be, which was built on budget deficit. Thousands of public sector workers protested against the austerity measures. Papandreou has secured parliamentary support for the measures, despite growing public opposition to his austerity program. The first three rounds of fiscal consolidation measures taken by the Papandreou government was supported by Greece's largest opposition party, the centre-right New Democracy (ND) which was unseated by PASOK in the 2009 elections, but it opposed the May 6, 2010, measures (Nelson, Belkin, Mix 2010: 10).

The policy solutions to two of the major economic issues facing the Greek government:

- Cutting large government budget deficits (which requires contractionary fiscal policies to address), and

- stimulating the economy during cyclical economic downturn (which requires expansionary fiscal policies)

- Contradicts with each other. Then the question is, how long the government will be able to rely on public support for the contractionary measures in the face of a sharp recession. ${ }^{4}$

\subsection{Greek government's response to the crisis-}

Facing with the intense cost of borrowing in the late 2009 and the beginning of 2010 the Greek government adopted a fiscal consolidation programme in order to diminish the public debt and stipulate the framework to improve stability and growth to the economy. The Greek Stability and Growth Programme were submitted to the European Commission on January 15, 2010. Its main elements on the revenues side were focused on (I) reduction of tax evasion and improve tax collection; (II) reduction of social contribution evasion (III) a special levy on profitable companies; (IV) acceleration of EU receipts for the public investment programme and (V) increase on several types of indirect taxes. Regarding the government expenditures, the following measures were taken, (I) a $10 \%$ cut in general government expenditure on salary allowances; (II) a recruitment freeze in the public sector for 2010; (III) implementation of a 5:1 retirement/recruitment ratio for public sector employees from 2011 onwards. Termination of many short-term contracts in the public sector, to cut operating expenditures for ministries by $10 \%$; (IV) reduction in the budget item linked to social security and pension funds by $10 \%$ and (v) other relevant measures to drastically reduce government expenditures in most public services (see also Arghyrou and Tsoukalas 2010).

\subsection{The rise of anti-austerity: rise of SYRIZA-}

May 2012 general elections proved the end of the bipolar era in Greek politics whereby the conservatives of ND and the socialists of PASOK lost the support of their prime days. SYRIZA became the main force of anti-austerity measures and firm opponents of neoliberalism.

\subsection{Bailout package of 2012-}

\footnotetext{
4،“Greece Economy: An Austere Future,” Economist Intelligence Unit, March 9, 2010.
} 
On 14 March 2012, the Euro group approved a second bailout package thereby "supporting" the second MAP for Greece (The MAPs were implemented and conducted by the Troika). The undisbursed amounts of the GLF along with an additional $€ 130$ billion was resolved which was to be disbursed in tranches between March 2012 and the end of 2014 by the eurozone member-states and the IMF. In this second package, the EFSF extended the loans committed by the euro-zone member states. The EFSF was to contribute $€ 144.7$ billion, while the IMF was to contribute $€ 19.8$ billion.

\subsection{Beneficiaries of bailouts-}

Greece's private lenders in general, and German and French banks in particular, benefited unequivocally from these bailouts. According to the Jubilee Debt Campaign, Greek and European financial institutions accounted for nearly 92\% of $€ 240$ billion, that the economy received since May 2010 bailout. Furthermore, the reformation in 2012 led to a possession transformation of the Greek public debt. The percentage of Greek public debt at the end of $2011(60 \%$ of $€ 356$ billion) was less than that at the end of 2012 (25\%). This percentage fell way below $20 \%$ of $€ 315$ billion Greek public debt at the end of 2014, with the Troika holding $78 \%$ of this debt.

Varoufakis was apparently correct in claiming that it is not the economy but its banks that got bailed out! The end result was of a deformed nation (far from being a reformed one).

\subsection{Third bailout programme negotiations-}

A provisional agreement was struck on a third bailout programme for Greece on 12th July 2015 meeting of Eurozone leaders, now this could total up to $€ 86$ billion in loans over three years. Formal negotiations on the detail of the programme were concluded in mid-August.

\subsection{Terms of the bailout programme-}

Greece was to implement a reform agenda (similar to those agreed in the $12^{\text {th }}$ July, 2015 Eurozone leaders' summit statement) including: • Reform of the pension system, removing exemptions and ending early retirement; •Deregulate labour and product markets, with the aim of increasing competition, competitiveness and investment in the economy; •Fight corruption by improving efficiency of the public sector and judiciary; •Implement a strengthened privatisation programme, including setting up a fund containing Greek assets that will either be sold or used to earn financial returns; • Improve financial stability by strengthening the banking sector.

\subsection{Political situation in Greece-}

SYRIZA came to power in election (In January 2015, promising not to implement austerity measures). The Greek people decisively rejected the bailout package (with over $61 \%$ vote) and voiced their opposition to anymore austerity. The European Central Bank then stopped financial transaction with Greek Banks leading to the possibility of financial bankruptcy.

Faced with financial collapse, in a dramatic reversal, Tsipras agreed to receive its first instalment of loans from the newly-signed third Eurozone bailout agreement and called for new elections to be held on 20 September. The Prime Minister accepting the terms of the new bailout agreement dissatisfied a significant minority of SYRIZA MPs who went on to vote against it in parliament. Many of the dissatisfied SYRIZA rebels broke away and formed a new political party called Popular Unity. They vouched to fight against the austerity measures and called for the cancellation of some of Greece's debt and a move away from euro currency to drachma ${ }^{5}$ (Harari 2015: 27).

\footnotetext{
5 "Greek crisis: SYRIZA rebels form Popular Unity party ahead of election", Guardian, 21 Aug 2015
} 


\subsection{Reaction to austerity after third bailout-}

Many commentators felt that Greek government and Prime Minister Tsipras had conceded important ground to get an agreement and keep Greece in the Eurozone. ${ }^{6}$ Many noted that the terms of the deal were harsher than those offered by creditors at the end of June 2015 that was rejected by the government and the Greek electorate in the referendum. On the contrary, this time around, negotiations were for an entirely new bailout agreement with a substantial greater amount of money being offered over a three-year period. Tsipras posited that negotiations were difficult but he claimed some successes too: financing over the medium-term, the potential for debt relief and stopping the $€ 50$ billion fund of Greek assets being based outside of Greece. ${ }^{7}$

\section{GREEK CRISIS - A MARXIAN RENDITION}

The mainstream explanations of Greek crisis, rooted either in neo-classical or neo-Keynesian economics, reflect three perspectives (Mavroudeas 2015: 4).

(a) The first one (coming from the European pundits from the dominant EU circles) identifies the Greek crisis as a 'Greek disease' (caused by special policy errors and structural deficiencies). This perspective was criticized for considering the Greek case as a national issue emerging from bad policies.

(b) The second perspective arises from Anglo-Saxon commentators and stresses on EMU's structural deficiencies and fundamental flaws that cannot be rectified. It argues that, EMU is a Non-Optimal Currency Area (OCA), prone to asymmetric shocks that aggravate national 'diseases'.

(c) The third version is a policy-driven (national disease) cum EMU's rectifiable structural flaws. It is argued that the Greek crisis originated from the existing flaws of EMU which can be rectified.

The second and third perspective recognises weak structural causes arise from the sphere of circulation and neglects the sphere of production.

On the other side, there was an upsurge of Radical Political Economy analysis stemming from post Keynesian and Marx-Keynesian perspectives. The radical approaches indicate that capitalism is crisis-prone in nature and try to show the Greek and European capitals as responsible for the crisis. They also criticised the EMU's neo-liberal structure and propose either for its eradication or radical overhaul. However, it is also true that they did not posit a strategy leading to socialist transition and focused primarily on overturning neoliberalism. Therefore, their point of attack is neoliberalism and not capitalism per se. Moreover, they bend to the financialization thesis and neglect the production sphere.

The Marxist explanation of the Greek crisis provides a strong structural narrative by attributing the fundamental causes of the Greek crisis to problems in the sphere of production. It emphasises two structural components. First, it argues that 2007-08 economic crisis is stemming from the tendency of the profit rate to fall (henceforth, TRPF), and not a primarily financial crisis. This represents the 'internal' cause of the Greek crisis. Second, it shows that- apart from the 'internal' cause - there are also 'external' causes coming from relations of imperialist exploitation (i.e. unequal exchange) that exist within the EU and which divide it between North (euro-core) and South (europeriphery) economies. It is needless to mention that Greece belongs to the second group (Mavroudeas 2015: 5).

According to the Marxian analysis, deep crises are not the outcome of accidental events or wrong policies, but a fettering of the accumulation process due to the lack of alternative profitable opportunities; this causes crisis in

\footnotetext{
${ }^{6}$ See for example, FastFT, "Now what? Reactions to the Greek deal”, 13 Jul 2015

${ }^{7}$ Guardian, Greek crisis live blog 13 Jul 2015 12:20pm entry
} 
capitalism. Marxist explanations use their Labour Theory of Value (LTV) tools and the focus on the profit rate (Mavroudeas 2015: 24). Three main Marxist explanations proposed are:

\subsection{A TRPF crisis-}

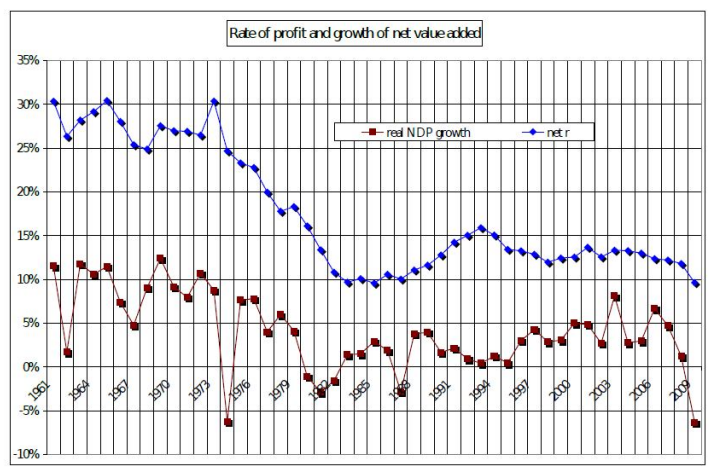

Source: Maniatis and Passas (2013)

Figure-13: The rate of profit and real output growth 1961-2009

The phase from 1958 to about mid 1970s: characterized as the 'golden age' of Greek capitalism:

$I^{\text {st }}$ Stage: high profit rates (despite a slightly falling trend) led to high rates of capital accumulation and output growth, significant rise in productivity growth and real wage for productive workers and workers in general even with a rising rate of surplus-value.

$2^{\text {nd }}$ Stage: Stagflation crisis, (1973-1974 and lasted until 1985): The significant rise in OCC ${ }^{8}$ during the 'golden age' combined with the fall in the rate of surplus-value and the profit share after the fall of the military dictatorship, led to a sharp fall in profitability that affected negatively the investment, output growth, productivity, real wage growth and employment.

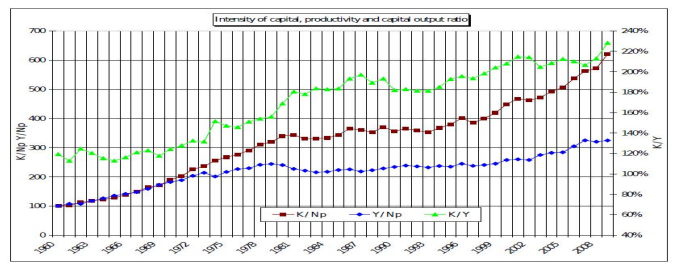

Figure-14: Technical composition of capital index, productivity index and capital/output ratio

Source: Maniatis and Passas (2013)

In the 1980's, the steady productivity rise (for slowdown in capital accumulation), the intensity of capital maintains its rising trend, as in the previous period. Since this application of new technologies does not lead to a rise in productivity, capital-output ratio rises throughout the decade, peaking at $200 \%$ at the late 80 's. Rate of surplus values falls, due to government policies undertaken in the following years since the fall of the military dictatorship,

\footnotetext{
${ }^{8}$ Rate of profit $(\mathrm{p})=\mathrm{s} /(\mathrm{c}+\mathrm{v})=(\mathrm{s} / \mathrm{v}) /(\mathrm{c} / \mathrm{v}+1)$, where $\mathrm{c}$ is constant capital, $\mathrm{s} / \mathrm{v}$ is rate of exploitation or rate of surplus value and $\mathrm{c} / \mathrm{v}$ is organic composition of capital (OCC).
} 
and the rate of unproductive labour begins to rise (Fig-18). These factors combined together, pull down profit ratio (Fig-14), and thus profit share, and - due to unproductive labour mostly - profit wage ratio (Vogiatzoglou 2013: 1314).

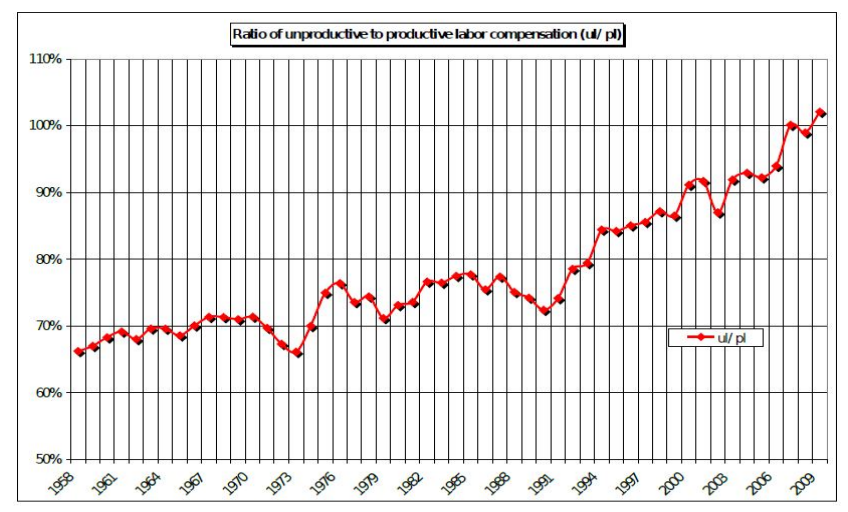

Figure-15: Ratio of unproductive labour to productive labour compensation

After 1986 (and especially after 1991) the third phase of neoliberalism begins, leading to a dramatic upturn in labour exploitation. The resultant recovery in profitability was not coupled with a sufficient devalorisation of capital and also output growth the last being achieved through the indirect impact of the financial bubbles created mostly by expansive monetary policy of that period. Those bubbles, first in the stock exchange market and then in the real estate sector created significant 'wealth effects' for households stimulating consumption demand, the only source of growth during this period. However, when all the bubbles burst the crisis erupted in 2009. The crisis resurfaced due to the low profitability of capital and as a result the rising OCC that could not be offset any more by increases in the rate of surplus-value or some expansionary fiscal or monetary policy.

(Mavroudeas 2015: 25-26).

\subsection{Reasons behind the Greek profitability crisis-}

Economakis, Androulakis and Markaki (2014) study of the Greek economy for the period 1960-2012 reveals that during the 'golden era' of Greek capitalism the profit rate increased sharply, reached its peak in 1973. The proxy variable for the OCC was low for this period thus increasing the profitability. Moreover, although wages increased, it lagged behind labour productivity rise, leading to fall of labour share of income.

During the next phase (1974-85) OCC increased contributing to the falling profitability trend that ended in 1985 , when PASOK turned to neoliberal restrictive policies. In the 1986-2006 phase of neoliberal policies, there was a non-significant reduction in the OCC leading to weak recovery of profitability, attributed to insufficient destruction of capital during the crisis. Finally, the last phase is that of the crisis (2007-12) when there is rapid fall in profitability leading to the lowest levels for the entire 1960-2012 period, accompanied by a dramatic increase of the OCC.

This study infers that the Greek debt crisis is a competitiveness crisis. The profitability of the Greek economy gets much diminished, as it was mainly on productive sectors not exposed to the international competition (non-tradable goods and services). Therefore, the depression that followed the troika austerity policies led to a sharp decline of profitability, mainly due to activation of the underconsumptionist factor of the crisis which is also the form of Greek capitalism's deep problems (Mavroudeas 2015: 25-27).

\subsection{A dual crisis of over accumulation from TRPF and imperialist exploitation-}

Mavroudeas (2013) and Mavroudeas and Paitaridis (2014) proposed a third Marxist explanation of the Greek crisis that emphasises the 'external' dimension, positing that Greece is middle-range capitalism with limited imperialist power. It continuously strives to exploit other areas and is in turn prone to exploitation from its more developed western partners. 
Greek capital made the strategic choice of European integration to upgrade Greek capitalism from middle-range imperialism to a partner in one of the major global imperialist blocs, but this process removed trade protectionism and massively reduced Greek capital's competitiveness against the more developed EEC economies. The conservative Keynesian policies delivered limited results as they failed to suppress adequately wages and devalorise over accumulated capitals. They were succeeded by the already dominant Western neo-liberal restructuring policies.

1985-2007 was marked by capitalist restructuring which strived to reverse the falling profit rate trend and the overaccumulation of capital by

(a) Increasing the rate of surplus-value,

(b) Reducing the value of labour-power,

(c) Reducing the value of constant capital,

(d) Reducing turnover time,

(e) Increasing foreign trade, and

(f) Reaping imperialist extra-profits from abroad.

But restructurings were only partially successful because the recovery of the profit rate never took it to the level before its fall, capital was devalorised. The tricks of 'financialization' and the 'artificial growth' only postponed the crisis and at that time augmented further the problem of overaccumulation. This crisis is characterized as a dual crisis of overaccumulation (caused by the TRPF) and imperialist exploitation (that traumatized Greek capital's profitability and productive structure). In the twin deficits of the dual crisis - the fiscal deficit worsened as the state subsidised the private sector.

\section{VIII.CONCLUSION}

In this project, we examined how the three inter-related factors - political situation in Greece, its relation with EU and EMU and eventually, the adoption of neoliberalism and financialization - as a result of their overdetermined and contradictory effects in 1978-2008, brought into effect, the sovereign debt crisis. More specifically, the austerity measures embody the contradictions that appeared in the Greek economy. As a result, the picture that emerged was one of political upheaval in Greece along with the shift of politics and its relationship with the EU and EMU.

The Marxian analysis gives a description of the mechanism of the crisis using the factors of TRPF, profitability crisis and overaccumulation. It also suggests the mechanism of imperialism as a force playing behind the screen.

\section{REFERENCES}

[1] Arghyrou, M. G. and Tsoukalas, J. D. (2010), "The Greek debt crisis: Likely causes, Mechanics and Outcomes" Cardiff Economics Working Papers E2010/3.

[2] Bank of Greece, (2010) The Greek economy stabilisation programme: Main points on the support mechanism, mimeo.

[3] Epstein, G. A. (2005) "Financialization and the world economy”, (UK: Edward Elgar Publishing).

[4] Harari, D. (2015) "Greek Debt Crisis: Background and Developments", Briefing paper, House of Commons Library.

[5] Hardouvelis, G.A., 2011a, "The Greek and European crisis and the new architecture of the Eurozone", Economy and the Markets Bulletin, EFG Eurobank.

[6] Hardouvelis, G. A., 2011b, "The Greek crisis, its resolution and implications for the EU and beyond", Joint Vienna Institute, mimeo.

[7] Kotz, D. (2009) "The Financial and Economic Crisis of 2008: A Systemic Crisis of Neoliberal Capitalism", Review of Radical Political Economics, 41, pp. 305-317.

[8] Lapavitsas, K. (1999) “Central bank independence: Problematic theory and empirical evidence”. In Vlachou 2012.

[9] Maniatis, T. and Passas, C. (2013) "Profitability Capital Accumulation and Crisis in the Greek Economy 1958-2009: a Marxist Analysis", Review of Political Economy, 25:4, pp. 624-649.

[10] Markantonatou, M. (2013) "Neoliberal State Regulation and the Bail out of Global Capitalism in the Recent Economic Crisis", (review article), in critical sociology, 2012, vol.39, issue 1, 2013.

[11] Mavroudeas, S. D. (2015) "The Greek Saga: Competing Explanations Of The Greek Crisis", Kingston University London Discussion Paper 2015-1.

[12] Nelson, R. M., Belkin, P. \& Mix, D. E. (2010) "Greece's Debt Crisis: Overview, Policy responses and Implications", Congressional Research Service, pp. 2-3.

[13] Vives, X. (1991). "Regulatory reform in European banking," European Economic Review, Elsevier, vol. 35(2-3), pp 505-515, April.

[14] Vlachou, A. and G. Christou. 1999. "Contemporary economic theory: Critical issues". In Vlachou 2012 